(6)

OPEN ACCESS

\title{
Wunderlich's syndrome in pregnancy: a shocking triad
}

Daniel Kane, ${ }_{1}^{1}$ Mona Abdelrahman, ${ }^{1}$ Aisling T Looney, ${ }^{\circ 2}$ Maeve Eogan ${ }^{1}$

Rotunda Hospital, Dublin, Ireland

${ }^{2}$ Department of Urology, University Hospital Waterford, Waterford, Ireland

Correspondence to

Dr Daniel Kane,

danielkane@rcsi.ie

Accepted 3 May 2019

\section{SUMMARY}

Wunderlich's syndrome, non-traumatic renal

haemorrhage into the subscapular and perinephric space, in pregnancy, is a very rare clinical entity. We describe a case of Wunderlich's syndrome in a 29-year-old gravida 5 para 4 who presented to our emergency department with sudden onset severe left flank pain. On assessment, she was clinically shocked-hypotensive, tachycardic and perfused poorly peripherally. Ultrasound of the abdomen and pelvis and subsequent MRI of the left kidney revealed a large hypervascular exophytic lesion arising from the left renal pole-appearance consistent with an angiomyolipoma. This specific presentation is clinically characterised as Lenk's triad-acute flank pain, flank mass and hypovolaemic shock. The patient was adequately resuscitated and interventional radiological embolisation of the mass was performed. She went on to have an uneventful pregnancy and delivered vaginally after induction at 38 weeks of gestation.

\section{BACKGROUND}

Wunderlich's syndrome, which was described by Wunderlich in 1856, is a rare and life-threatening condition which is characterised by non-traumatic renal haemorrhage into the subscapular and perinephric space. ${ }^{1}$ It is a very rare clinical entity in pregnancy and as of yet there is no clear guidance as to how these should be managed in pregnancy. ${ }^{2}$

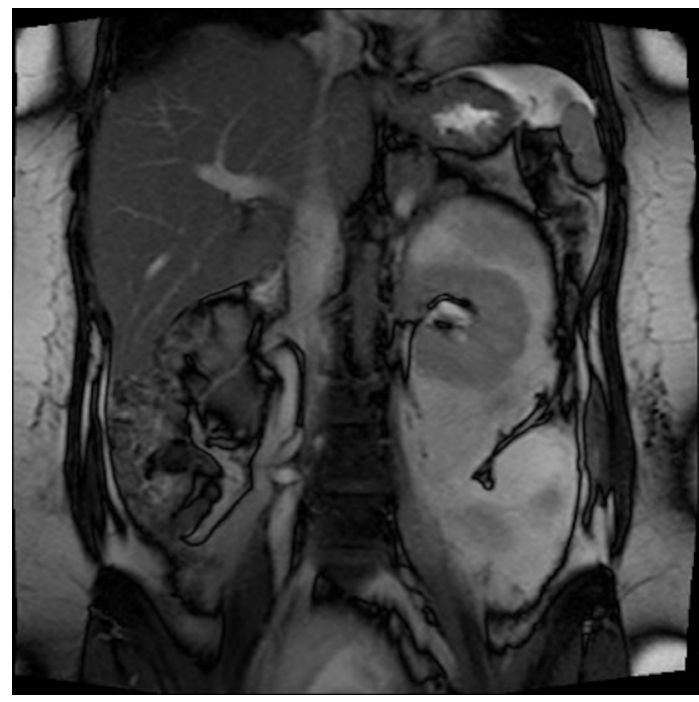

Figure 1 MRI image of abdomen showing left-sided renal mass in the upper renal pole with retroperitoneal haemorrhage.

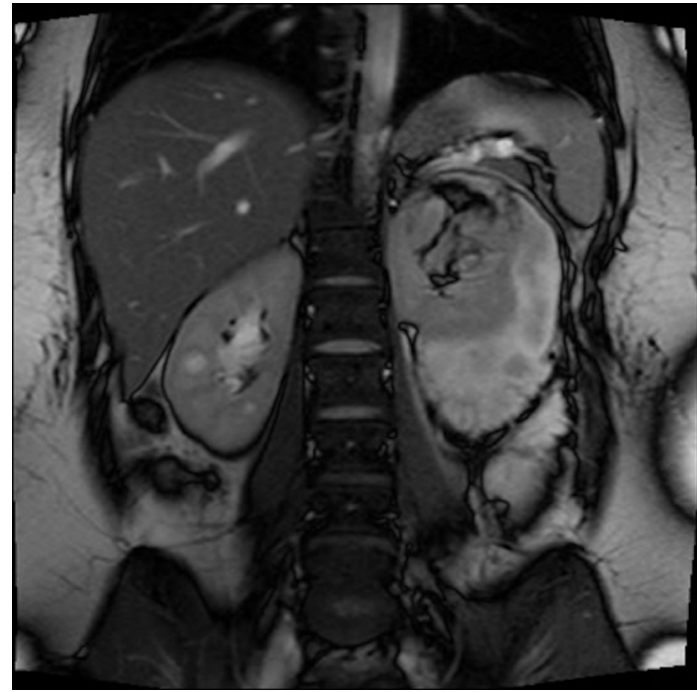

Figure 2 MRI image of abdomen showing the leftsided renal mass in the upper renal pole.

\section{CASE PRESENTATION}

A 29-year-old gravida 5 para 4, collapsed at home at $17+3$ week's gestation following the sudden onset of severe left-sided flank pain. She had an uneventful pregnancy until this presentation, having booked at 12 weeks of gestation with a singleton intrauterine pregnancy.

She was brought in by ambulance. She gave a history of sudden severe onset of left-sided abdominal pain with no history of any trauma. She had no significant previous medical or surgical history and had no significant family history.

On examination, she was noted to be pale and diaphoretic, apyrexial, blood pressure of $73 / 38 \mathrm{~mm} \mathrm{Hg}$, heart-rate of $95 \mathrm{bpm}$ and an respiratory rate of 14 . Her abdomen was soft, with appropriate distension for her gravid state and she had marked left-sided flank tenderness. There was no evidence of ecchymosis.

\section{INVESTIGATIONS}

Initial investigations showed a haemaglobin of $87 \mathrm{~g} / \mathrm{L}$, white cell count of $20.4 \times 10^{9} / \mathrm{L}$, C-reactive protein of 62 and a lactate of 2.23. Urine dipstick showed +3 ketones with no haematuria. A focused obstetric ultrasound showed an intrauterine pregnancy of 17 weeks of gestational age.

An ultrasound of her abdomen and pelvis revealed a $6 \times 7 \mathrm{~cm}$ complex mass arriving from the left kidney. An MRI scan of her abdomen showed a large hypervascular exophytic lesion arising from the left renal pole, which contained multiple small 


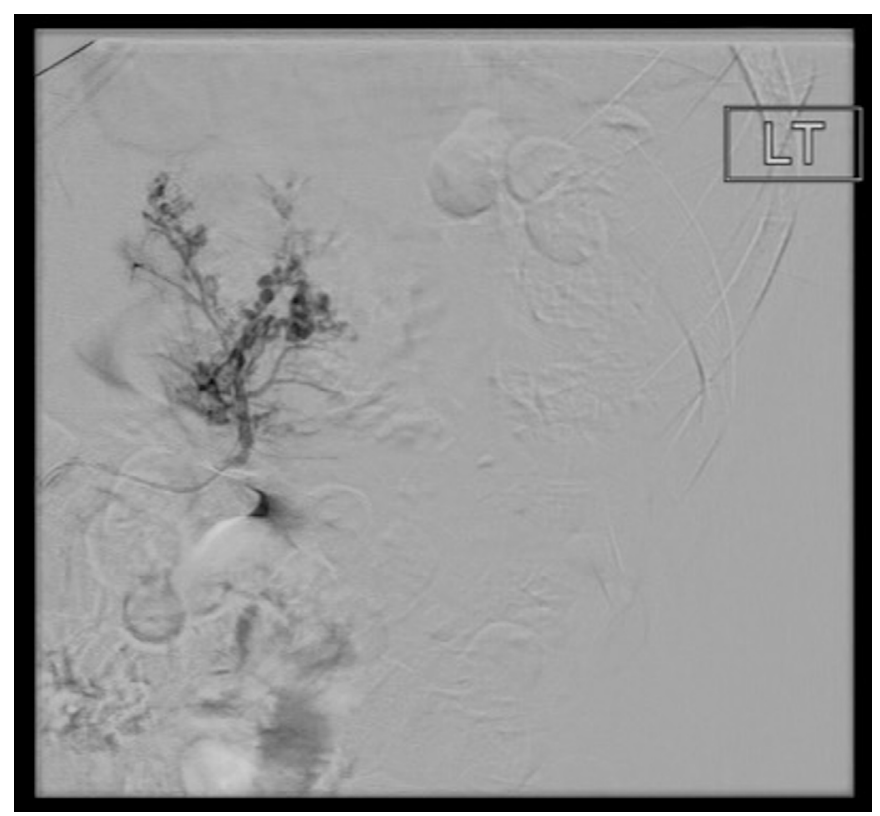

Figure 3 IR fluoroscopy image of left renal angiomyolipoma, prior to embolisation. IR, interventional radiological.

pseudoaneurysms and tortuous abnormal-appearing arteries consistent with an angiomyolipoma (figures 1 and 2).

\section{TREATMENT}

The patient was fluid resuscitated and transfused with two units of packed red cells after a repeat haemoglobin of $59 \mathrm{~g} / \mathrm{L}$. Once

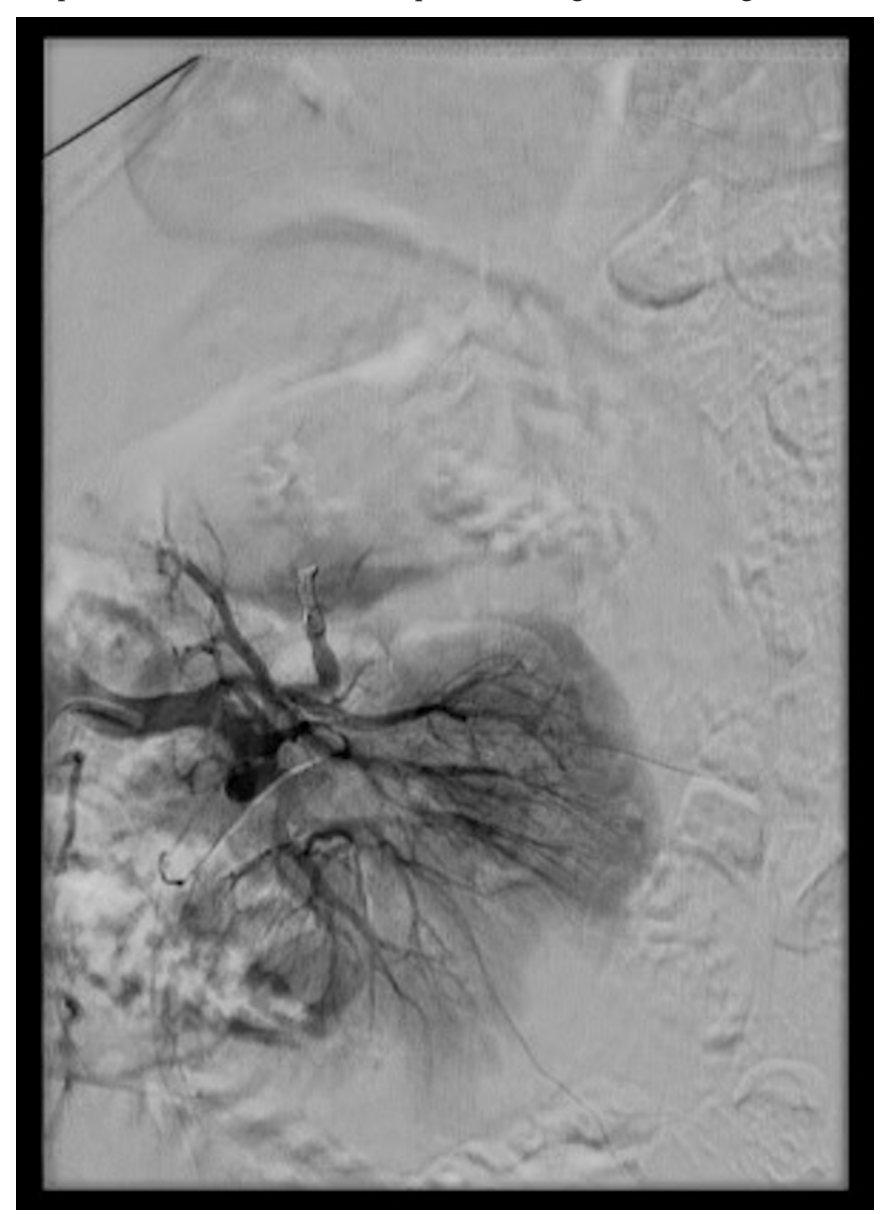

Figure 4 IR fluoroscopy image of left renal $A M L$, postembolisation. IR, interventional radiological. stabilised and with an improved haemoglobin level, the patient was transferred to a tertiary referral unit, where a urology opinion was obtained. Following review of the patient and the available imaging, the decision was made to recommend interventional radiological embolisation of the tumour's feeding renal artery (figures 3 and 4), in an effort to effectively control haemorrhage while preserving nephrons. The interventional radiologist was aware of the patient's gravid status, and maximal precautions were taken to minimise radiation exposure for the patient and the fetus.

\section{OUTCOME AND FOLLOW-UP}

The patient was discharged 4 days postembolisation. She was then reviewed every few weeks in the consultant-led antenatal clinic in our institution. The rest of her antenatal course was uneventful.

She was induced at 38 weeks of gestation and had an uncomplicated spontaneous vaginal delivery. She will be reviewed in the urology outpatient department going forward with postpartum renal imaging, due to her childbearing age and risk of further AML haemorrhage.

\section{DISCUSSION}

This is a unique case of Wunderlich's syndrome in pregnancy, as it is the first described case in Ireland and is also one of only four documented cases in pregnancy who went on to have a vaginal delivery with a preserved kidney.

Angiomyolipomas are benign mesenchymal tumours. They are four times more likely in women, and are sometimes associated with tuberous sclerosis (TS). They may have irregular and aneurysmatic blood vessels. The major risk factors for bleeding are tumour size $(>4 \mathrm{~cm})$ and the presence of TS. Indications for intervention are pain, bleeding or suspected malignancy. Selective arterial embolisation is an efficient treatment for AML devascularisation and useful in controlling haemorrhage in the acute setting, but often more definitive surgical management is required (eg, partial nephrectomy). ${ }^{3}$

Wunderlich's syndrome is a feared and sometimes fatal complication of AMLs. As AMLs are hormone sensitive (with 25\% of them displaying progesterone and oestrogen receptors), they are therefore more likely to increase in size during pregnancy and rupture. ${ }^{4}$ For that reason, many urologists favour close observation of women with known AMLs that are of childbearing age.

A literature review has shown that most reported cases during pregnancy had ruptured (80\%). ${ }^{5}$

Management of this condition is case dependent as there is a paucity of evidence in the literature to support a definite management pathway in pregnancy. Treatment should be tailored depending on the patient's haemodynamic stability, the size of the tumour and whether they are symptomatic or not.

\section{Learning points}

- The mode of delivery should be dictated by obstetrics indications and not solely by the presence of an AML.

- Vaginal delivery is safe if there is no obstetric contraindication.

- Preservation of the kidney is possible if the patient is haemodynamically stable or asymptomatic.

- It is important to consider renal AML as a differential for a renal mass during pregnancy, as their complications can be catastrophic.

- In an asymptomatic pregnant patient, a conservative approach, including active surveillance can often be adopted. 
In an asymptomatic pregnant patient, a conservative approach, including active surveillance can often be adopted, but close monitoring by urology is recommended. ${ }^{2}$

Contributors DK-author/obstetrics team - involved in patient's care. MAsecond author/obstetrics team-involved in patient's care. ATL-third author and urologist—involved in patient care. ME — consultant obstetrician—involved in patient's care.

Funding The authors have not declared a specific grant for this research from any funding agency in the public, commercial or not-for-profit sectors.

Competing interests None declared.

Patient consent for publication Obtained.

Provenance and peer review Not commissioned; externally peer reviewed.

Open access This is an open access article distributed in accordance with the Creative Commons Attribution Non Commercial (CC BY-NC 4.0) license, which permits others to distribute, remix, adapt, build upon this work non-commercially, and license their derivative works on different terms, provided the original work is properly cited and the use is non-commercial. See: http://creativecommons.org/ licenses/by-nc/4.0/

\section{REFERENCES}

1 Polkey HJ. Spontaneous nontraumatic perirenal and renal hematomas. Arch Surg 1933:26:196.

2 Illescas Molina T, Montalvo Montes J, Contreras Cecilia E, et al. tuberous sclerosis and pregnancy. Ginecol Obstet Mex 2009;77:380-6.

3 EAU. EAU Guidelines. 2018 http://uroweb.org/guideline/renal-cell-carcinoma/

4 Morales JP, Georganas M, Khan MS, et al. Embolization of a bleeding renal angiomyolipoma in pregnancy: case report and review. Cardiovasc Intervent Radiol 2005;28:265-8.

5 Çetin C, Büyükkurt S, Demir C, et al. Renal angiomyolipoma during pregnancy: Case report and literature review. Turk J Obstet Gynecol 2015;12:118-21.

6 Medda M, Picozzi SC, Bozzini G, et al. Wunderlich's syndrome and hemorrhagic shock. J Emerg Trauma Shock 2009;2:203-5.

Copyright 2019 BMJ Publishing Group. All rights reserved. For permission to reuse any of this content visit

https://www.bmj.com/company/products-services/rights-and-licensing/permissions/

BMJ Case Report Fellows may re-use this article for personal use and teaching without any further permission.

Become a Fellow of BMJ Case Reports today and you can:

- Submit as many cases as you like

- Enjoy fast sympathetic peer review and rapid publication of accepted articles

- Access all the published articles

- Re-use any of the published material for personal use and teaching without further permission

For information on Institutional Fellowships contact consortiasales@bmjgroup.com

Visit casereports.bmj.com for more articles like this and to become a Fellow 